\title{
Genotoxic Potential and Physicochemical Parameters of Sinos River, Southern Brazil
}

\author{
Madalena C. S. Scalon, ${ }^{1}$ Ciliana Rechenmacher, ${ }^{2}$ Anna Maria Siebel, ${ }^{2}$ \\ Michele L. Kayser, ${ }^{3}$ Manoela T. Rodrigues, ${ }^{3}$ Sharbel W. Maluf, ${ }^{4}$ Marco Antonio S. \\ Rodrigues, ${ }^{5}$ and Luciano Basso da Silva ${ }^{6}$ \\ ${ }^{1}$ Programa de Pós-graduação em Qualidade Ambiental, Universidade Feevale, 93352-000 Novo Hamburgo, RS, Brazil \\ ${ }^{2}$ Curso de Ciências Biológicas, Universidade Feevale, 93352-000 Novo Hamburgo, RS, Brazil \\ ${ }^{3}$ Curso de Biomedicina, Universidade Feevale, 93352-000 Novo Hamburgo, RS, Brazil \\ ${ }^{4}$ Laboratório de Citogenética, Serviço de Genética Médica, Hospital de Clínicas de Porto Alegre, \\ 90035-903 Porto Alegre, RS, Brazil \\ ${ }^{5}$ Programa de Pós-graduação em Qualidade Ambiental, Grupo de Pesquisa em Tecnologias Ambientais, \\ 93352-000 Novo Hamburgo, RS, Brazil \\ ${ }^{6}$ Programa de Pós-graduação em Qualidade Ambiental, Grupo de Pesquisa em Indicadores de Qualidade Ambiental, \\ Universidade Feevale, RS 239, No. 2755, 93352-000 Novo Hamburgo, RS, Brazil
}

Correspondence should be addressed to Luciano Basso da Silva; lucianosilva@feevale.br

Received 27 August 2013; Accepted 16 September 2013

Academic Editors: T. Coccini and T. Gupta

Copyright (C) 2013 Madalena C. S. Scalon et al. This is an open access article distributed under the Creative Commons Attribution License, which permits unrestricted use, distribution, and reproduction in any medium, provided the original work is properly cited.

\begin{abstract}
The present study aimed to evaluate the physicochemical parameters and the genotoxic potential of water samples collected in the upper, middle, and lower courses of the Sinos River, southern Brazil. The comet assay was performed in the peripheral blood of fish Hyphessobrycon luetkenii exposed under laboratory conditions to water samples collected in summer and winter in three sampling sites of Sinos River. Water quality analysis demonstrated values above those described in Brazilian legislation in Parobé and Sapucaia do Sul sites, located in the middle and in the lower courses of the Sinos River, respectively. The Caraá site, located in the upper river reach, presented all the physicochemical parameters in accordance with the allowed limits in both sampling periods. Comet assay in fish revealed genotoxicity in water samples collected in the middle course site in summer and in the three sites in winter when compared to control group. Thus, the physicochemical parameters indicated that the water quality of the upper course complies with the limits set by the national guidelines, and the ecotoxicological assessment, however, indicated the presence of genotoxic agents. The present study highlights the importance of combining water physicochemical analysis and bioassays to river monitoring.
\end{abstract}

\section{Introduction}

Rivers receive a huge amount of wastes from urban areas and industrial and agricultural activities [1]. Hence, water bodies will be contaminated with complex, ill-defined mixtures of chemicals and most freshwater organisms will be exposed, to varying degrees, to this contamination [2]. In this context, chemical analysis of water is not sufficient to assess their toxic potential for wildlife and humans. This is because the bioavailability, the biological activities, and interactions between different environmental chemicals are not completely understood and considered when hazard assessments and predictions of possible ecotoxicological effects are made based on concentrations alone [3]. Therefore, a simultaneous application of bioassays is a good complement to chemical analyses and a useful tool to establish the ecological effects to environment, as it provides the complete response of test organisms to all the compounds in the water [4]. 
Among the methods available to assess the many possible toxic effects caused by the chemicals present in the environment, the analysis of DNA alterations in aquatic organisms has been shown to be a highly suitable method for evaluating the genotoxic contamination of environments, being able to detect toxicity at low concentrations of contaminants in a wide range of species [5]. The pollution-induced genetic damage might cause adverse effects to species and affect the stability of ecosystems [6-8]. The comet assay or single cell gel electrophoresis is a rapid, sensitive, and relatively inexpensive method to study DNA damage in different cell types and has found wide application in genotoxicity evaluation in fish exposed to various xenobiotics in the aquatic environment $[1,9]$. The comet assay is based on the ability of negatively charged fragments of DNA to be drawn through an agarose gel in response to an electric field. The extent of DNA migration depends directly on the DNA damage present in the cells [1].

The subtropical Sinos River is one of the main rivers located in Brazil's southernmost state, Rio Grande do Sul, and is an example of an impacted watercourse. The Sinos River basin presents an area of approximately $4,000 \mathrm{~km}^{2}$, which covers 32 municipalities, and provides drinking water for 1.2 million inhabitants and for one of the most important industrial centers in Brazil [10]. In the downriver direction, the river is divided into upper, middle, and lower courses, following a gradient of pollution. The Sinos River in the upper course has low demographic density and suffers moderate impacts from small amounts of agricultural waste and relatively little influence from domestic sewage. The middle course has a major impact with large areas used for rice cultivation and cattle ranching and has a larger number of inhabitants. In the lower course the demographic density and concentration of industries are high [10]. The most densely populated urban areas include three cities with more than 200,000 inhabitants (Novo Hamburgo, São Leopoldo, and Canoas), which are located in the lower course of the river.

Studies by the State Environmental Protection Agency (Fundação Estadual de Proteção Ambiental, FEPAM) revealed high loads of domestic and industrial sewage in the lower course of the Sinos River [10]. Moreover, some chemical parameters in the middle course revealed that its water quality index was similar to that of the lower region of the basin [11]. Studies investigating the genotoxicity of water samples collected from the Sinos River have yielded both positive [12-14] and negative [14-17] results.

In our previous investigation of genotoxicity of Sinos River, the results suggested that the sampling site near the river spring is not appropriate as reference site to fish genotoxicity bioassays [13]. Therefore, the aim of the present study was to evaluate the water quality of Sinos River through physicochemical parameters and genotoxic assay using the fish Hyphessobrycon luetkenii as organism test.

\section{Materials and Methods}

2.1. Sampling Sites. Water samples were collected in March and July 2008 (summer and winter, resp.) at three sampling sites: in the upper Sinos River course, near the river spring (town of Caraá: S $29^{\circ} 43^{\prime} 26^{\prime \prime}$ and W $50^{\circ} 16^{\prime} 46$ ), in the middle course (town of Parobé: S $29^{\circ} 41^{\prime} 05^{\prime \prime}$ and W $50^{\circ} 50^{\prime} 52^{\prime \prime}$ ), and in the lower river course (town of Sapucaia do Sul: S $29^{\circ} 47^{\prime} 53^{\prime \prime}$ and $\mathrm{W} 51^{\circ} 11^{\prime} 24^{\prime \prime}$ ).

2.2. Fish Bioassay. Healthy juvenile specimens of indigenous fish species Hyphessobrycon luetkenii (Boulenger, 1887) (Characidae) were obtained from a local fish farm. Animals were randomly divided into four groups of about 12 specimens and placed in a $10 \mathrm{~L}$ aquarium, with welloxygenated, dechlorinated tap water at $21^{\circ} \mathrm{C} \pm 2^{\circ} \mathrm{C}$, for a $96 \mathrm{~h}$ acclimatization period; they were then released into $10 \mathrm{~L}$ aquariums with undiluted water samples from each site within $4 \mathrm{~h}$ after sampling. Tap water was used as negative control group. The exposure period was $48 \mathrm{~h}$ with no food supply.

2.3. Comet Assay. After the exposure period, the comet assay was performed on peripheral erythrocytes, according to Tice et al. [19]. Slides were precoated with normal melting point agarose. A mixture of $5 \mu \mathrm{L}$ of blood sample collected from caudal veins of fish with $95 \mu \mathrm{L}$ low melting point agarose $(0.7 \%)$ was added to the slide and immediately covered with a coverslip and then kept for $10 \mathrm{~min}$ in a refrigerator to solidify. After solidification of the gel, coverslips were gently removed and the slides were immersed in cold, freshly made lysing solution $(2.5 \mathrm{M} \mathrm{NaCl}, 100 \mathrm{mM}$ EDTA, and $10 \mathrm{mM}$ Tris, $\mathrm{pH}$ 10.2 , to which $1 \%$ Triton X-100 and $10 \%$ DMSO had been added) and refrigerated at $4^{\circ} \mathrm{C}$ for $6-24 \mathrm{~h}$. After the lysis, the slides were placed in a horizontal electrophoresis box side by side. The tank was filled with fresh electrophoresis buffer $(300 \mathrm{mM} \mathrm{NaOH}$ and $1 \mathrm{mM}$ EDTA, $\mathrm{pH}>13)$ at $4^{\circ} \mathrm{C}$. The liquid covered the slides, which were then left in the solution for $20 \mathrm{~min}$ before the power was turned on. Electrophoresis was performed at $25 \mathrm{~V}$ and $300 \mathrm{~mA}(\sim 0.95 \mathrm{~V} / \mathrm{cm})$ for $20 \mathrm{~min}$. The steps above were carried out under red light to avoid induction of DNA damage. After electrophoresis, the slides were gently removed from the tank, and neutralizing buffer (0.4 M Tris, $\mathrm{pH} 7.5$ ) was added to the slides dropwise three times, letting it sit for $5 \mathrm{~min}$ each time. The slides were rinsed three times with distilled water, air-dried for at least $24 \mathrm{~h}$, and then fixed and stained with silver stain according to Nadin et al. [20].

For evaluation of DNA damage, 100 cells per individual were analyzed under an optical microscope at 400x magnification. The analysis of the slides was conducted using the quality assurance criteria suggested by Tice et al. [19]. All slides were coded and examined blind by the same observer. The cells were visually scored according to tail length into five classes, from undamaged (class 0 ) to complete damage (class 4) [21]. Value was assigned to the different categories (from class $0=0$ to class $4=4$ ) and a damage index was calculated $[($ No. of class 0 cells $\times 0)+($ No. of class 1 cells $\times 1)$ $+($ No. of class 2 cells $\times 2)+($ No. of class 3 cells $\times 3)+($ No. of class 4 cells $\times 4$ )] for each fish [22]. Therefore, the total score per individual ranged from 0 (all undamaged) to 400 (all maximally damaged). The damage frequency was calculated 
as the percentage of damaged cells (e.g., the sum of cells with damage classes 1 to 4 ).

2.4. Physicochemical Analysis. Immediately after collection, water samples were analyzed according to Standard Methods for the Examination of Water and Wastewater [23]. The following parameters were analyzed: $\mathrm{pH}$, chemical oxygen demand (COD), five-day biological oxygen demand $\left(\mathrm{BOD}_{5}\right)$, conductivity, chlorides, hardness, total nitrogen, ammoniacal nitrogen, phosphorus, aluminum, lead, chromium, copper, nickel, iron, zinc, sodium, total solids, dissolved solids, total volatile solids, nitrite, nitrate, turbidity, dissolved oxygen (DO), total coliforms, and fecal coliforms (Escherichia coli).

2.5. Statistical Analysis. Statistical analysis was performed using ANOVA, followed by Tukey multiple comparison test when appropriate. All analyses were carried out using the Statistical Package for the Social Sciences (SPSS) 15.0 for Windows, considering a significance level of $P \leq 0.05$.

\section{Results}

The values of physicochemical variables measured in the three sampling sites during the summer and winter seasons are shown in Table 1 . The values were compared to CONAMA Resolution 357/2005 by the Environment National Council [18] for classifying the national water bodies. In this legislation, the freshwater systems were allocated to five classes (from the class 1 to the class 4, water quality decreases and restrictions to water use as drinking supply increase) and upper limits were fixed for different water variables for each category (some of them for class 2 category are shown in Table 1). Freshwater systems within class 2 category may be used for human supply (after treatment), aquatic biological community protection, recreation, irrigation, aquaculture, and fishing activities.

Concerning the nineteen water parameters with reference values defined by CONAMA Resolution $n$. 357, higher values than standards were observed in sites Parobé and Sapucaia do Sul. Higher values were observed in Parobé for aluminum, iron, and fecal coliforms in the two sampling periods, for total phosphorus in summer, and for BOD in winter. The two water samples of Sapucaia do Sul showed BOD, conductivity, total phosphorus, iron, dissolved oxygen, and fecal coliforms values at odds with the CONAMA resolution, in addition to aluminum and copper in the winter sample. The Caraá site presented all the physicochemical parameters in accordance with the allowed limits in both sampling periods.

The results of damage frequency (\%) and damage index estimated by the comet assay in the erythrocytes of $H$. luetkenii exposed to water samples from three sampling sites in the Sinos River and to tap water (control) are summarized in Table 2. In the summer period, damage frequency at Parobé site was significantly higher than that found at Caraá and in the control group; however, no differences in damage index were observed. The fish exposed to water samples collected at the three sampling sites in winter have shown significant increase in both damage index and damage frequency when compared to control group.

\section{Discussion}

Resolution $n .357$ [18] is a guiding tool used to evaluate water quality in Brazil, and in the present study, values above those described in resolution were observed at sites Parobé and Sapucaia do Sul, located in the middle and lower courses of the Sinos River, respectively. Thus, water quality tended to decrease downstream as the river passes through the densely urbanized and industrial areas and receives discharge of treated and untreated domestic and industrial effluents [24]. According to the Sinos River Basin Management Committee, at present, domestic sewage is considered to be the major problem affecting water quality of the Sinos River because only $10 \%$ of domestic sewage is treated. The results obtained for dissolved oxygen indicated anoxic conditions of water in Sapucaia do Sul, the lower course site. Moreover, Parobé and Sapucaia do Sul showed fecal coliforms and $\mathrm{BOD}_{5}$ values higher than the limits, possibly as a consequence of high organic matter input from untreated domestic sewage discharge [25].

Apart from the domestic sewage, the Sinos River also receives pollutants from industrial and rural waste, which have been reported as a source of toxic and mutagenic effects on the environment $[5,26]$. Studies on the genotoxicity of Sinos River basin have yielded conflicting results. Absence of genotoxic activity was found in the Salmonella/microsome test [15], the micronuclei analysis in the V79 cell line (Chinese hamster lung fibroblasts) [16], the wing somatic mutation and recombination test (SMART) in Drosophila melanogaster [17] and the Allium cepa test (micronucleus test) [14]. On the other side, Vargas et al. [15] have found genotoxic effects in the microscreen phage-induction assay and Lemos et al. [12] using Salmonella/microsome assay found indicative mutagenic response, including in the headwaters of a tributary of the Sinos River. Moreover, Nunes et al. [14] found positive results in V79 cell line (comet assay and micronucleus test).

Although the in vitro tests used in most studies assessing Sinos River genotoxicity are recommended methods to evaluate the mutagenic activity of environmental samples, such tests do not provide an assessment of genotoxicity in ecologically relevant organisms [27], such as fish species. In the first study in which Sinos River water genotoxicity was assessed using fish biomarkers, the comet assay has shown significant differences between sampling periods, with higher values in water samples collected at sites in the upper and middle course during the spring season [13]. The results suggested that sites near the river spring are not appropriate as reference sites to fish genotoxicity bioassays. In addition, based on the monitoring of physicochemical parameters of Sinos River water, Blume et al. [11] have concluded that the sampling sites in the upper course should no longer be used as a reference point in future studies.

In the present study, the water samples collected in the summer in the middle course site and in the winter in the three sites have shown genotoxicity in the peripheral blood of 
TABle 1: Physicochemical parameters of water samples from different sites of Sinos River in the summer and winter of 2008.

\begin{tabular}{|c|c|c|c|c|c|c|c|}
\hline \multirow[t]{2}{*}{ Parameter } & \multirow[t]{2}{*}{ CONAMA } & \multicolumn{2}{|c|}{$\begin{array}{c}\text { Caraá } \\
\text { Upper course }\end{array}$} & \multicolumn{2}{|c|}{$\begin{array}{c}\text { Parobé } \\
\text { Middle course }\end{array}$} & \multicolumn{2}{|c|}{$\begin{array}{l}\text { Sapucaia do Sul } \\
\text { Lower course }\end{array}$} \\
\hline & & Summer & Winter & Summer & Winter & Summer & Winter \\
\hline $\mathrm{BOD}_{5}, \mathrm{mgO}_{2} \mathrm{~L}^{-1}$ & 5.0 & $<1.0$ & 1 & 1 & $7^{*}$ & $7^{*}$ & $12^{*}$ \\
\hline $\mathrm{COD}, \mathrm{mgO}_{2} \mathrm{~L}^{-1}$ & - & 8 & 2 & 10 & 7 & 15 & 34 \\
\hline Chlorides, $\mathrm{mg} \mathrm{L}^{-1}$ & 250 & 3.1 & 2.9 & 2.9 & 3.5 & 12.2 & 10.7 \\
\hline Conductivity, $\mu \mathrm{S} \mathrm{cm}^{-1}$ & 100 & 32.75 & 29 & 69.05 & 68.45 & $142.85^{*}$ & $119.7^{*}$ \\
\hline Hardness, $\mathrm{mgCaCO}_{3} \mathrm{~L}^{-1}$ & - & 7 & 13 & 22 & 29 & 31 & 42 \\
\hline Total nitrogen, $\mathrm{mg} \mathrm{L}^{-1}$ & - & 1.3 & $<0.5$ & 2.28 & $<0.5$ & 3.91 & $<0.5$ \\
\hline Ammoniacal nitrogen, $\mathrm{mg} \mathrm{L}^{-1}$ & 3.7 & nd & $<0.5$ & nd & $<0.5$ & 1.46 & $<0.5$ \\
\hline Total phosphorus, $\mathrm{mg} \mathrm{L}^{-1}$ & 0.1 & nd & $<0.012$ & $0.105^{*}$ & 0.06 & $0.201^{*}$ & $1.075^{*}$ \\
\hline Aluminum, $\mathrm{mg} \mathrm{L}^{-1}$ & 0.1 & 0.05 & nd & $0.59^{*}$ & $0.18^{*}$ & 0.05 & $2.0^{*}$ \\
\hline Lead, $\mathrm{mg} \mathrm{L}^{-1}$ & 0.01 & nd & nd & nd & 0.0015 & nd & 0.004 \\
\hline Chromium, $\mathrm{mg} \mathrm{L}^{-1}$ & 0.05 & nd & nd & nd & nd & nd & 0.04 \\
\hline Copper, $\mathrm{mg} \mathrm{L}^{-1}$ & 0.009 & nd & nd & 0.002 & nd & 0.004 & $0.04^{*}$ \\
\hline Nickel, mg L ${ }^{-1}$ & 0.025 & nd & nd & nd & nd & nd & 0.01 \\
\hline Iron, $\mathrm{mg} \mathrm{L}^{-1}$ & 0.3 & 0.08 & 0.23 & $1.93^{*}$ & $0.66^{*}$ & $1.13^{*}$ & $6.88^{*}$ \\
\hline Zinc, $\mathrm{mg} \mathrm{L}^{-1}$ & 0.18 & 0.01 & nd & 0.01 & nd & 0.01 & 0.08 \\
\hline Sodium, $\mathrm{mg} \mathrm{L}^{-1}$ & - & 5 & 5.4 & 6 & 6.9 & 13.4 & 14.1 \\
\hline Dissolved solids, $\mathrm{mg} \mathrm{L}^{-1}$ & 500 & 10.5 & 77 & 35.5 & 91 & 17 & 110 \\
\hline Total solids, $\mathrm{mg} \mathrm{L}^{-1}$ & - & 51.5 & 197 & 117.5 & 215 & 169 & 870 \\
\hline Total volatile solids, $\mathrm{mg} \mathrm{L}^{-1}$ & - & 34.5 & 144 & 75.5 & 133 & 105 & 227 \\
\hline $\mathrm{pH}$ & 6.0 to 9.0 & 7.46 & 7.06 & 7.21 & 7.28 & 6.89 & 6.89 \\
\hline Nitrates, $\mathrm{mg} \mathrm{L}^{-1}$ & 10.0 & 1.09 & 0.12 & 2.83 & 1.42 & 2.18 & 1.28 \\
\hline Nitrite, $\mathrm{mg} \mathrm{L}^{-1}$ & 1.0 & nd & 0.003 & 0.04 & 0.04 & 0.16 & 0.12 \\
\hline Turbidity, NTU & 100 & 0.42 & 0.02 & 17.4 & 0.9 & 12.4 & 50.5 \\
\hline Dissolved oxygen, $\mathrm{mg} \mathrm{L}^{-1}$ & 5.0 & 8.13 & 8.53 & 7.31 & 7.11 & $4.47^{*}$ & $2.03^{*}$ \\
\hline Total coliforms, NMP/100 mL & - & 5012 & 697 & 101120 & 68930 & 56300 & 23100 \\
\hline Fecal coliforms, NMP/100 mL & 1000 & 85 & 84 & $2690^{*}$ & $8620^{*}$ & $3000^{*}$ & $5200^{*}$ \\
\hline
\end{tabular}

Values were obtained from one water sample. nd: not detected. ${ }^{*}$ Values at odds with the CONAMA resolution $n .357 / 05$ upper limits to class 2 water category [18].

TABLE 2: Damage frequency (the sum of cells with damage classes 1 to 4 , in $\%$ ) and damage index estimated by the comet assay (mean \pm standard deviation) in the erythrocytes of $H$. luetkenii exposed to water samples from the Sinos River and to tap water (control).

\begin{tabular}{|c|c|c|c|c|}
\hline \multirow{2}{*}{ Sampling site } & \multicolumn{2}{|c|}{ Summer } & \multicolumn{2}{|c|}{ Winter } \\
\hline & Damage frequency $(n)$ & Damage index & Damage frequency $(n)$ & Damage index \\
\hline $\begin{array}{l}\text { Caraá } \\
\text { (Upper course) }\end{array}$ & $50.6 \pm 9.3(12)^{\mathrm{a}}$ & $58.1 \pm 14.5$ & $66.3 \pm 13.3(11)^{\mathrm{a}}$ & $69.5 \pm 14.2^{\mathrm{a}}$ \\
\hline $\begin{array}{l}\text { Parobé } \\
\text { (Middle course) }\end{array}$ & $61.3 \pm 6.3(12)^{\mathrm{b}}$ & $64.6 \pm 7.4$ & $62.9 \pm 16.0(8)^{\mathrm{a}}$ & $65.3 \pm 17.9^{\mathrm{a}}$ \\
\hline $\begin{array}{l}\text { Sapucaia do Sul } \\
\text { (Lower course) }\end{array}$ & $53.3 \pm 10.4(12)^{\mathrm{ab}}$ & $60.8 \pm 16.0$ & $59.6 \pm 11.5(11)^{\mathrm{a}}$ & $62.5 \pm 15.0^{\mathrm{a}}$ \\
\hline Control & $47.1 \pm 11.5(12)^{\mathrm{a}}$ & $51.1 \pm 14.2$ & $40.4 \pm 16.0(8)^{\mathrm{b}}$ & $40.4 \pm 16.0^{\mathrm{b}}$ \\
\hline$P$ & 0.005 & 0.107 & 0.002 & 0.002 \\
\hline
\end{tabular}

The number of fish analyzed in each sample is presented between brackets. $P$ values referring to ANOVA between sampling sites and respective control group $\left({ }^{\mathrm{a}, \mathrm{b}}\right.$ values with different letters have significant difference in the same column). 
$H$. luetkenii when compared to negative control, confirming the results of other studies that have detected contamination of genotoxic compounds in the Sinos River basin, including the upstream course $[12,13]$. Thus, the results of this study indicate that native fish species might be at risk for genotoxic damage in the Sinos River. However, the genotoxic potential of contaminants is an organism-specific and exposuredependent phenomenon and interspecies variability for toxic responses as a result of differences in uptake, accumulation, metabolism, excretion, and DNA repair efficiency should be considered [8].

Many studies investigated the genotoxic effects of rural, industrial, and urban effluents; however, their relative contribution and comprehensive chemical characterization remain a major challenge $[26,28,29]$. Considering the low urban density and the economic activities in the upper Sinos River site (Caraá), this region suffers relatively little influence from domestic and industrial sewage and genotoxic pollutants might come from small farms and livestock. Contaminants in this region threaten the sustainability of one of the main basins of southern Brazil, responsible for water supply to approximately 1.6 million inhabitants, representing $17 \%$ of the population of the Rio Grande do Sul state [24]. Further studies in the upper Sinos River course should be conducted to identify sources of water contaminants so that measures can be taken to reduce or eliminate their negative effects.

\section{Conclusion}

Physicochemical parameters demonstrated decreasing water quality from upstream to downstream of the Sinos River and comet assay in fish showed that the river water may be contaminated with genotoxic pollutants in the upper, middle, and lower courses. Thus, despite good water quality of the upper river course, it should no longer be used as a reference site in future genotoxicity studies. Moreover, the results showed that complementing the physicochemical evaluation of river water with bioassays clearly permits acquisition of information that cannot be obtained from the measurement of water quality parameters.

\section{Acknowledgments}

This work was partially supported by a research Grant from Conselho Nacional de Desenvolvimento Científico e Tecnológico (CNPq, no. 477192/2007-6) and by a Student Fellowship from Fundação de Amparo à Pesquisa do Estado do Rio Grande do Sul (FAPERGS) to an undergraduate student (CR).

\section{References}

[1] G. Frenzilli, M. Nigro, and B. P. Lyons, "The Comet assay for the evaluation of genotoxic impact in aquatic environments," Mutation Research, vol. 681, no. 1, pp. 80-92, 2009.

[2] J. P. Sumpter, "Protecting aquatic organisms from chemicals: the harsh realities," Philosophical Transactions of the Royal Society A, vol. 367, no. 1904, pp. 3877-3894, 2009.
[3] C. Wang, Y. Wang, F. Kiefer, A. Yediler, Z. Wang, and A. Kettrup, "Ecotoxicological and chemical characterization of selected treatment process effluents of municipal sewage treatment plant," Ecotoxicology and Environmental Safety, vol. 56, no. 2, pp. 211-217, 2003.

[4] C. Blasco and Y. Picó, "Prospects for combining chemical and biological methods for integrated environmental assessment," Trends in Analytical Chemistry, vol. 28, no. 6, pp. 745-757, 2009.

[5] R. Van der Oost, J. Beyer, and N. P. E. Vermeulen, "Fish bioaccumulation and biomarkers in environmental risk assessment: a review," Environmental Toxicology and Pharmacology, vol. 13, no. 2, pp. 57-149, 2003.

[6] J. W. Bickham, S. Sandhu, P. D. N. Hebert, L. Chikhi, and R. Athwal, "Effects of chemical contaminants on genetic diversity in natural populations: implications for biomonitoring and ecotoxicology," Mutation Research, vol. 463, no. 1, pp. 33-51, 2000.

[7] M. H. Medina, J. A. Correa, and C. Barata, "Micro-evolution due to pollution: possible consequences for ecosystem responses to toxic stress," Chemosphere, vol. 67, no. 11, pp. 2105-2114, 2007.

[8] A. N. Jha, "Ecotoxicological applications and significance of the comet assay," Mutagenesis, vol. 23, no. 3, pp. 207-221, 2008.

[9] A. Dhawan, M. Bajpayee, and D. Parmar, "Comet assay: a reliable tool for the assessment of DNA damage in different models," Cell Biology and Toxicology, vol. 25, no. 1, pp. 5-32, 2009.

[10] FEPAM. Fundação Estadual de Proteção Ambiental Henrique Luiz Roessler, Qualidade ambiental-Região Hidrográfica do Guaíba. Qualidade das águas da Bacia Hidrográfica do Rio dos Sinos. 2009, http://www.fepam.rs.gov.br/qualidade/ qualidade_sinos/sinos.asp.

[11] K. K. Blume, J. C. Macedo, A. Meneguzzi, L. B. Silva, D. M. Quevedo, and M. A. S. Rodrigues, "Water quality assessment of the Sinos River, Southern Brazil," Brazilian Journal of Biology, vol. 70, no. 4, pp. 1185-1193, 2010.

[12] A. T. Lemos, D. P. Rosa, J. A. V. Rocha, and V. M. F. Vargas, "Mutagenicity assessment in a river basin influenced by agricultural, urban and industrial sources," Ecotoxicology and Environmental Safety, vol. 72, no. 8, pp. 2058-2065, 2009.

[13] M. C. S. Scalon, C. Rechenmacher, A. M. Siebel et al., "Evaluation of Sinos River water genotoxicity using the comet assay in fish," Brazilian Journal of Biology, vol. 70, no. 4, pp. 1217-1222, 2010.

[14] E. A. Nunes, C. T. De Lemos, L. Gavronski, T. N. Moreira, N. C. D. Oliveira, and J. da Silva, "Genotoxic assessment on river water using different biological systems," Chemosphere, vol. 84, no. 1, pp. 47-53, 2011.

[15] V. M. F. Vargas, S. B. Migliavacca, A. C. De Melo et al., "Genotoxicity assessment in aquatic environments under the influence of heavy metals and organic contaminants," Mutation Research, vol. 490, no. 2, pp. 141-158, 2001.

[16] N. R. Terra, I. R. Feiden, J. Fachel, C. T. Lemos, and E. A. Nunes, "Ecotoxocological evaluation of sediment and water samples from Sinos River, Rio Grande do Sul, Brazil, using Daphnia magna and V79 cells," Acta Limnologica Brasiliensia, vol. 20, no. 1, pp. 63-72, 2008.

[17] L. V. Jacociunas, R. R. Dihl, M. Lehmann, M. L. Reguly, and H. H. R. de Andrade, "Recombinagenic activity of water and sediment from Sinos River and Araçá and Garças Streams (Canoas, Brazil), in the Drosophila wing spot test," Science of the Total Environment, vol. 408, no. 3, pp. 571-577, 2010. 
[18] Conselho Nacional do Meio Ambiente-CONAMA, Resolução n. 357/2005. Dispõe sobre a classificação dos corpos de água e diretrizes ambientais para o seu enquadramento, bem como estabelece as condições e padrões de lançamento de efluentes, e dá outras providências. Diário Oficial da União, Brasília, Brasil, Mars 2005.

[19] R. R. Tice, E. Agurell, D. Anderson et al., "Single cell gel/comet assay: guidelines for in vitro and in vivo genetic toxicology testing," Environmental and Molecular Mutagenesis, vol. 35, no. 3, pp. 206-221, 2000.

[20] S. B. Nadin, L. M. Vargas-Roig, and D. R. Ciocca, "A silver staining method for single-cell gel assay," Journal of Histochemistry and Cytochemistry, vol. 49, no. 9, pp. 1183-1186, 2001.

[21] D. Anderson, T.-W. Yu, B. J. Phillips, and P. Schmezer, “The effect of various antioxidants and other modifying agents on oxygenradical-generated DNA damage in human lymphocytes in the COMET assay," Mutation Research, vol. 307, no. 1, pp. 261-271, 1994.

[22] M. Pitarque, A. Creus, R. Marcos, J. A. Hughes, and D. Anderson, "Examination of various biomarkers measuring genotoxic endpoints from Barcelona airport personnel," Mutation Research, vol. 440, no. 2, pp. 195-204, 1999.

[23] APHA. American Public Health Association, Standard Methods for the Examination of Water and Wastewater, Washington, DC, USA, 20th edition, 1998.

[24] Comitesinos, "Comitê de Gerenciamento da Bacia Hidrográfica do Rio dos Sinos. Caracterização da Bacia Hidrográfica do Rio dos Sinos," 2000, http://www.comitesinos.com.br/.

[25] P. R. Kannel, S. Lee, S. R. Kanel, S. P. Khan, and Y.-S. Lee, "Spatial-temporal variation and comparative assessment of water qualities of urban river system: a case study of the river Bagmati (Nepal)," Environmental Monitoring and Assessment, vol. 129, no. 1-3, pp. 433-459, 2007.

[26] T. Ohe, T. Watanabe, and K. Wakabayashi, "Mutagens in surface waters: a review," Mutation Research, vol. 567, no. 2-3, pp. 109149, 2004.

[27] A. N. Jha, T. H. Hutchinson, J. M. Mackay, B. M. Elliott, and D. R. Dixons, "Evaluation of the genotoxicity of municipal sewage effluent using the marine worm Platynereis dumerilii (Polychaeta: Nereidae)," Mutation Research, vol. 391, no. 3, pp. 179-188, 1997.

[28] L. D. Claxton, V. S. Houk, and T. J. Hughes, "Genotoxicity of industrial wastes and effluents," Mutation Research, vol. 410, no. 3, pp. 237-243, 1998.

[29] P. A. White and J. B. Rasmussen, "The genotoxic hazards of domestic wastes in surface waters," Mutation Research, vol. 410, no. 3, pp. 223-236, 1998. 

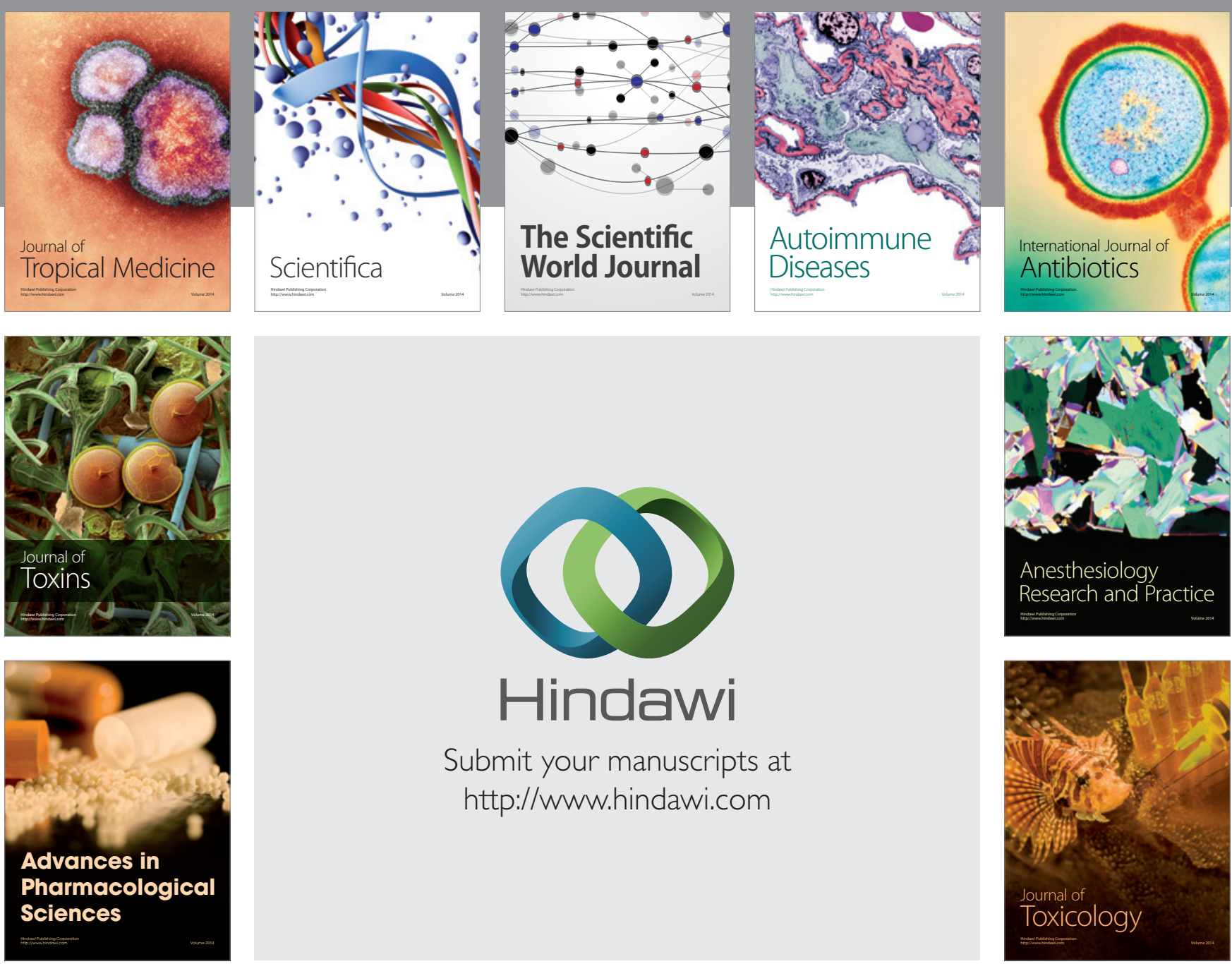

\section{Hindawi}

Submit your manuscripts at

http://www.hindawi.com
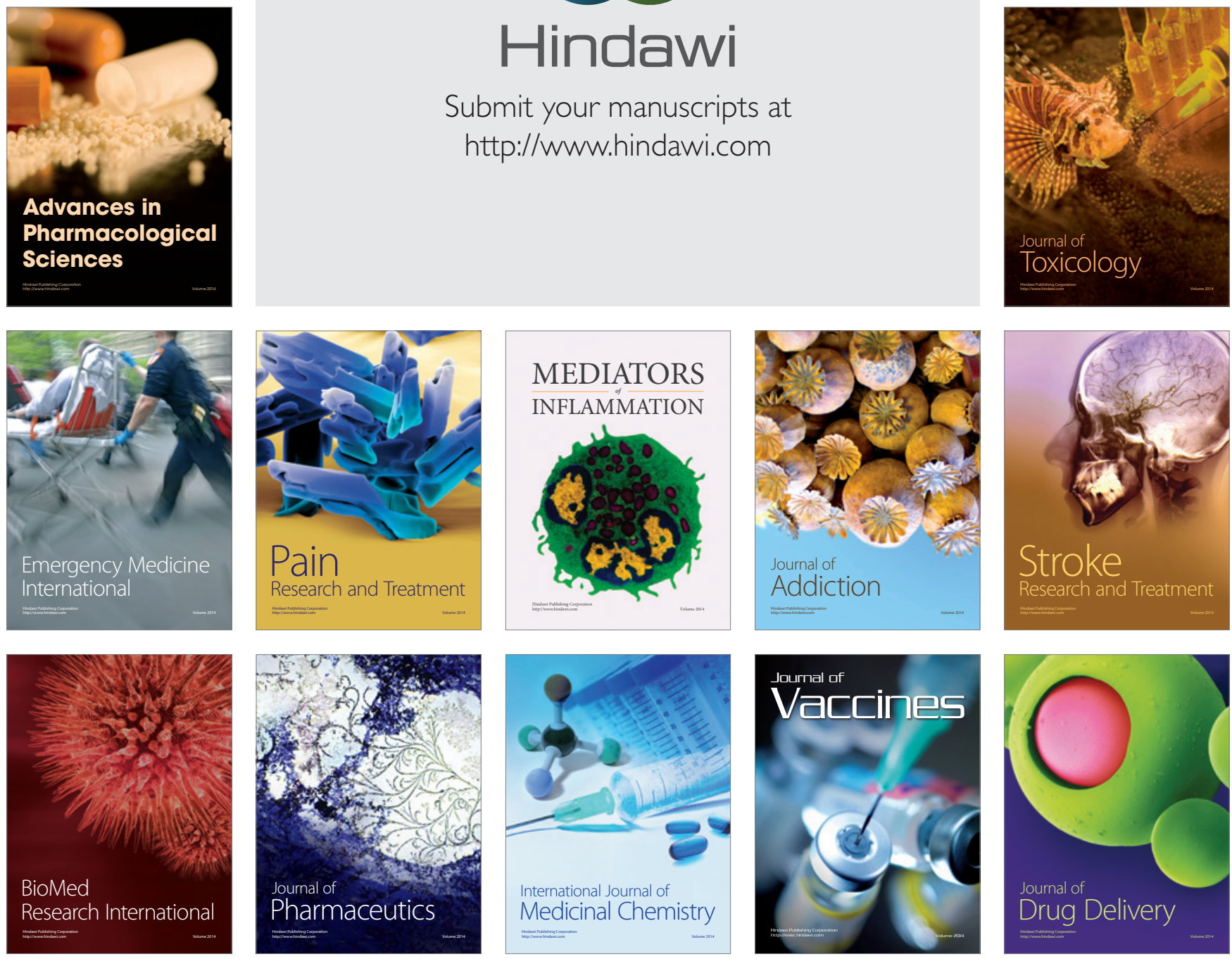